\title{
TCT (Trash Can Talk) Berbasis Arduino Dengan Sistem Solar Cell Untuk Sarana Pembelajaran Perilaku Tertib Buang Sampah pada Anak
}

Ida Afriliana ${ }^{1}$, Andi Setiawan ${ }^{2}$, Andre Juan Taftazani ${ }^{3}$, Heki Rahayu Navita ${ }^{4}$, Imam Bukhari ${ }^{5}$

12345 D3 Teknik Komputer Politeknik Harapan Bersama

\begin{abstract}
The activity of disposing of garbage becomes unpleasant because of lazy reasons so not many children prefer to litter and become one of the problems of PHBS in the school environment. The problem of littering is very dangerous if it is embedded in children because they are the younger generation of the nation's successors. The purpose of this research is to produce an Arduino-based TCT (Trash Can Talk) bin with a solar cell system for learning the orderly behavior of throwing garbage in children with research procedures from planning, analysis, design, and implementation by utilizing the Arduino Uno R3 microcontroller. , PIR sensor to detect the presence of children so that the trash can emits 2 sounds from the DF mini mp3 player through the speakers alternately to attract children's attention and the voice command "open" which is detected by the voice recognition sensor to open the trash can automatically and commands the "close" sound to close the trash bin will then emit a third sound from the DF mini mp3 player through the speakers for the children who have disposed of the trash in an orderly manner. The fourth sound from the DF mini mp3 player through the speaker as a full notification and the trash can can't open. The solar cell system is the main energy source to support environmentally friendly renewable energy.
\end{abstract}

Keywords: Arduino Uno, Solar Cell, Sensor, Sound

\section{Abstrak}

Kegiatan membuang sampah menjadi hal yang kurang menyenangkan karena alasan malas sehingga tak banyak anak-anak lebih memilih membuang sampah sembarangan dan menjadi salah satu masalah PHBS di lingkungan sekolah. Masalah membuang sampah sembarangan ini sangat berbahaya jika tertanam dalam diri anak-anak karena merupakan generasi muda penerus bangsa. Tujuan dari penelitian ini yaitu untuk menghasilkan tempat sampah TCT (Trash Can Talk) berbasis Arduino dengan sistem solar cell untuk sarana pembelajaran perilaku tertib buang sampah pada anak-anak dengan prosedur penelitian dari rencana, analisa, rancangan, dan implementasi dengan memanfaatkan mikrokontroler arduino uno R3, sensor PIR untuk mendeteksi keberadaan anak-anak sehingga tempat sampah dapat mengeluarkan 2 suara dari DF mini mp3 player melalui speaker secara bergantian untuk menarik perhatian anak-anak dan perintah suara "buka" yang dideteksi sensor voice recognition untuk membuka tempat sampah secara otomatis dan perintah suara "tutup" untuk menutup tempat sampah kemudian akan mengeluarkan suara ketiga dari DF mini mp3 player melalui speaker untuk anak-anak yang telah membuang sampah dengan tertib. Suara keempat dari DF mini mp3 player melalui speaker sebagai notifikasi penuh dan tempat sampah tidak bisa membuka. Sistem solar cell sebagai sumber tenaga utamanya untuk mendukung energi terbarukan yang ramah lingkungan.

Kata Kunci : Arduino Uno, Solar Cell, Sensor, Suara.

ISSN 2715-0143 (online) ISSN 2714-9048 (print)

http://journal.walisongo.ac.id/index.php/jit/index

WJIT : Walisongo Journal of Information Technology - Vol.3 No. 1 (2021) 


\section{PENDAHULUAN}

Perilaku Hidup Bersih dan Sehat (PHBS) adalah semua perilaku kesehatan yang dilakukan atas dasar kesadaran sehingga anggota keluarga dapat menolong dirinya sendiri di bidang kesehatan dan berperan aktif dalam kegiatan-kegiatan kesehatan di masyarakat [1]. Anak sekolah merupakan generasi penerus bangsa yang perlu dijaga, ditingkatkan dan dilindungi kesehatannya. Jumlah anak usia sekolah yang cukup besar yaitu $30 \%$ dari jumlah penduduk Indonesia merupakan masa keemasan untuk menanamkan PHBS sehingga anak sekolah berpotensi sebagai agen perubahan untuk mempromosikan PHBS, baik di lingkungan sekolah, keluarga maupun masyarakat [1].

Salah satu masalah perilaku hidup bersih dan sehat (PHBS) disekolah yang masih banyak terjadi yaitu membuang sampah tidak pada tempatnya. Membuang sampah sembarangan seringkali menjadi kebiasaan masih dilakukan banyak orang karena membuang sampah sembarangan mudah untuk dilakukan. Sampah yang ada di

penelitian dalam karya tulis ilmiah yang berjudul Smile Trash (Smart Learning Trash) Tempat Sampah Pembentuk Karakter Anak Bangsa [3]. Perancangan dan Pembuatan Smart Trash Bin Berbasis Arduino Uno [4]. Perancangan Sistem Smart Trash Can Menggunakan Arduino Dengan Sensor Ultrasonik HC-SR04 [5].

Arduino merupakan papan elektronik berbasis mikrokontroller ATMega yang memenuhi sistem lingkungan bila dikelola dengan baik maka akan menjadikan lingkungan baik maka akan menjadikan lingkungan yang baik pula, yaitu lingkungan yang bersih dan sehat akan tetapi pada kenyataannya masih sulit untuk diterapkan, semua itu dapat dilihat pada perilaku membuang sampah sembarangan yang masih dilakukan oleh anak sekolah, banyak sampah dibuang sembarangan baik itu diselokan, dan tempat-tempat lainnya, sampah yang dibuang dijalan, diselokan, seringkali dibiarkan bertumpuk. Adapun tujuan penelitian ini yaitu (1) menghasilkan alat TCT (Trash Can Talk) berbasis arduino untuk sarana pembelajaran perilaku tertib buang sampah pada anak-anak yang interaktif untuk diterapkan sehingga kegiatan membuang sampah dapat menjadi hal yang menyenangkan bagi anak-anak. (2) Sistem solar cell dapat diterapkan dalam TCT (Trash Can Talk) dalam mendukung energi terbarukan.

\section{METODE}

Adapun tahapan prosedur penelitian yang dilakukan sebagai berikut : (1) Rencana / Planning. Pada penelitian ini, dibuat sebuah tempat sampah yang interaktif dan menarik untuk anak-anak sebagai sarana pembelajaran perilaku tertib buang sampah dalam hal ini untuk mendukung pengembangan program PHBS (Perilaku Hidup Bersih dan Sehat) di lingkungan SD Negeri Gumalar 01 di Desa Gumalar Kecamatan Adiwerna Kabupaten Tegal. Arduino Uno R3 teknologi mikrokontroler arduino uno R3 dengan sensor PIR untuk mendeteksi keberadaan anak-anak sehingga tempat sampah mengeluarkan 2 suara 
TCT (Trash Can Talk) Berbasis Arduino Dengan Sistem Solar Cell Untuk Sarana Pembelajaran Perilaku Tertib Buang Sampah pada Anak

dari DF mini mp3 player melalui speaker yang dimainkan secara bergantian dan menggunakan perintah suara atau voice recognition untuk membuka dan meutup tempat sampah secara otomatis dan kemudian akan mengeluarkan suara ketiga dari DF mini mp3 player melalui speaker sebagai reward bagi anak-anak yang telah membuang sampah dengan tertib. Menggunakan suara keempat dari DF mini mp3 player melalui speaker sebagai pemberitahuan bahwa tempat sampah telah penuh. Dan sistem solar cell sebagai sumber tenaga untuk mendukung energi terbarukan yang ramah lingkungan. (2) Analisa. DariArduino Uno atau mikrokontroler seri [15].

Loudspeaker, speaker atau sistem speaker merupakan sebuah transduser elektroacoustical yang mengubah sinyal listrik ke suara. Istilah loudspeaker dapat dijadikan acuan sebagai transduser individual (diketahui sebagai pengarah). sensor - sensor atau modul yang dibutuhkan agar fungsi TCT (Trash Can Talk) berjalan dengan baik.

(3)Rancangan. Dalam metode rancangan diawali dengan menemukan masalah serta teknik pemecahan masalah tersebut, sehingga diperoleh tujuan dari penelitian. Adapun rancangan yang dibuat, meliputi rancangan hardware dan rancangan software. Rancangan hardware yang dibuat yaitu membuat sistem nyata, yang dapat diuji secara langsung. Adapun rancangan software, yaitu dengan membuat rancangan prototype sistem dengan bantuan flowchart dan skema rancangan hardware. (4) Implementasi. Pada penelitian ini,sistem akan diimplementasikan dalam bentuk menjadi alat TCT (Trash Can Talk) berbasis arduino dengan sistem solar cell sebagai sumber tenaga untuk sarana pembelajaran perilaku tertib buang sampah pada anak-anak di SDN Gumalar 01 di Desa Gumalar Kecamatan Adiwerna Kabupaten Tegal.

\section{Analisa dan Perancangan}

(1) Analisa. Tempat sampah yang ada di lingkungan sekolah SD Negeri Gumalar 01 di wilayah Desa Gumalar Kecamatan Adiwerna Kabupaten Tegal masih menggunakan perencanaan diatas, dapat dihasilkan bahwa dalam perakitan TCT (Trash Can Talk) membutuhkan referensi tools yang sesuai agar TCT (Trash Can Talk) dapat berfungsi dengan baik. Disamping itu, dibutuhkan juga materi dan referensi dalam pembuatan program (coding) yang menghubungkan Arduino Uno R3 dengan

(1) Laptop Acer Swift 3. (2) Arduino Uno R3. (3) Sensor Utrasonik HC-SR04.(4) Sensor PIR. (5) Sensor Voice Recognition. (6) DF Mini MP3 Player. (7) LED. (8) Motor Servo MG996R. (9) Solar Panel. (10) Aki kering ukuran 12 volt. (11) Solar Charger Controller. (12) StepDown.(13) Speaker. (14)Breadboard. (15) Kabel Jumper. (2) Perangkat Lunak. Perangkat lunak yang dibutuhkan dalam pembuatan TCT (Trash Can Talk) sebagai berikut: (1) Windows 10 ultimate. (2) Arduino IDE Software. (3) Fritzing.

(2) Perancangan Sistem. Perancangan diagram blok merupakan suatu pernyataan gambar yang ringkas, dari gabungan sebab dan akibat antara masukan dan keluar dari suatu sistem. 


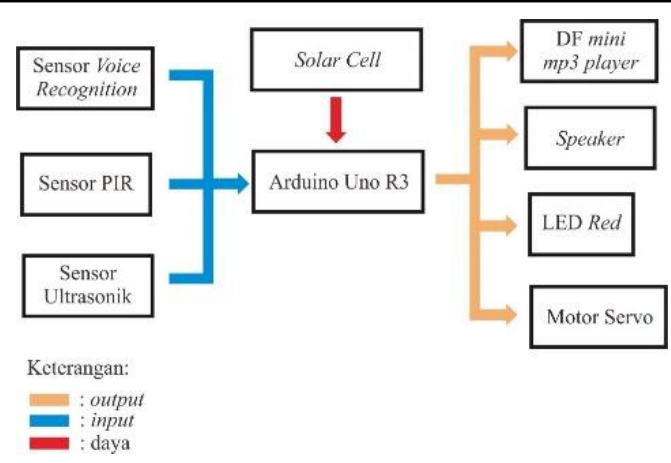

Gambar 1. Perancangan diagram blok TCT (Trash Can Talk)

(3). Perancangan Flowchart dengan cara manual untuk membukanya yang sedikit menyulitkan anak-anak untuk membuang sampah karena tidak mau bersentuhan takut kotor dengan tempat sampah sehingga tak banyak anak-anak lebih memilih membuang sampah sembarangan atau menyimpan sampah di laci meja belajar. Masalah membuang sampah sembarangan sangat berbahaya jika tertanam dalam diri anak-anak karena anak-anak merupakan generasi muda penerus bangsa.

Berdasarkan masalah tersebut maka dapat diambil suatu permasalahan yaitu bagaimana membuat tempat sampah yang interaktif dan dapat membuka tutup otomatis dan dapat mengeluarkan suara sebagai pembelajaran bagi anak-anak agar anak-anak tertarik untuk membuang sampah pada tempatnya dengan senang hati tanpa paksaan dari orang dewasa. Sehingga dapat terbentuk perilaku tertib membuang sampah pada anak-anak di lingkungan sekolah dasar tersebut. (1) Perangkat Keras. Kebutuhan alat (hardware) yang diperlukan untuk pembuatan TCT (Trash Can Talk) adalah sebagai berikut :

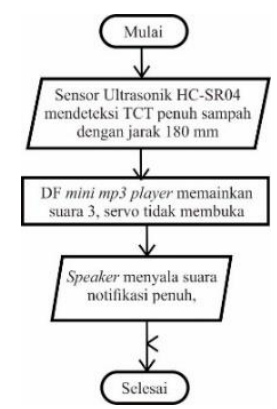

Gambar 3 Perancangan Flowchart TCT (Trash Can Talk) telah penuh

\section{KERANGKA TEORI}

Beberapa penelitian mengenai tempat sampah telah banyak dilakukan diantaranya Istilah loudspeaker dapat dijadikan acuan sebagai transduser individual (diketahui sebagai pengarah) atau sistem lengkap yang terdiri dari suatu enclosure yang melengkapi satu atau lebih pengarah dan komponen filter listrik. Loudspeaker sama halnya dengan transduser electroacoustical, merupakan elemen variabel; dalam system audio dan paling bertanggung jawab membedakan suara yang dapat didengar antar soundsystem [16]. minimum mikrokontroller agar dapat bekerja secara mandiri (standalone controller). Dalam berbagai aplikasi, arduino dapat digunakan untuk mendeteksi lingkungan dengan menerima input dari berbagai sensor atau tombol (sensor cahaya, suhu, inframerah, ultrasonik, jarak, tekanan, kelembaban) dan dapat mengontrol perangkat lainnya seperti mengontrol kecepatan dan arah putar motor, menyalakan LED, dan sebagainya [8].

Solar cell adalah sistem yang melibatkan solar panel atau solar cell yang bertugas mengumpulkan tenaga daripada matahari, yang mana tenaga itu kemudiannya digunakan untuk mengecas baterai, lalu baterai itulah yang membekalkan tenaga elektrik [9]. 
TCT (Trash Can Talk) Berbasis Arduino Dengan Sistem Solar Cell Untuk Sarana Pembelajaran Perilaku Tertib Buang Sampah pada Anak

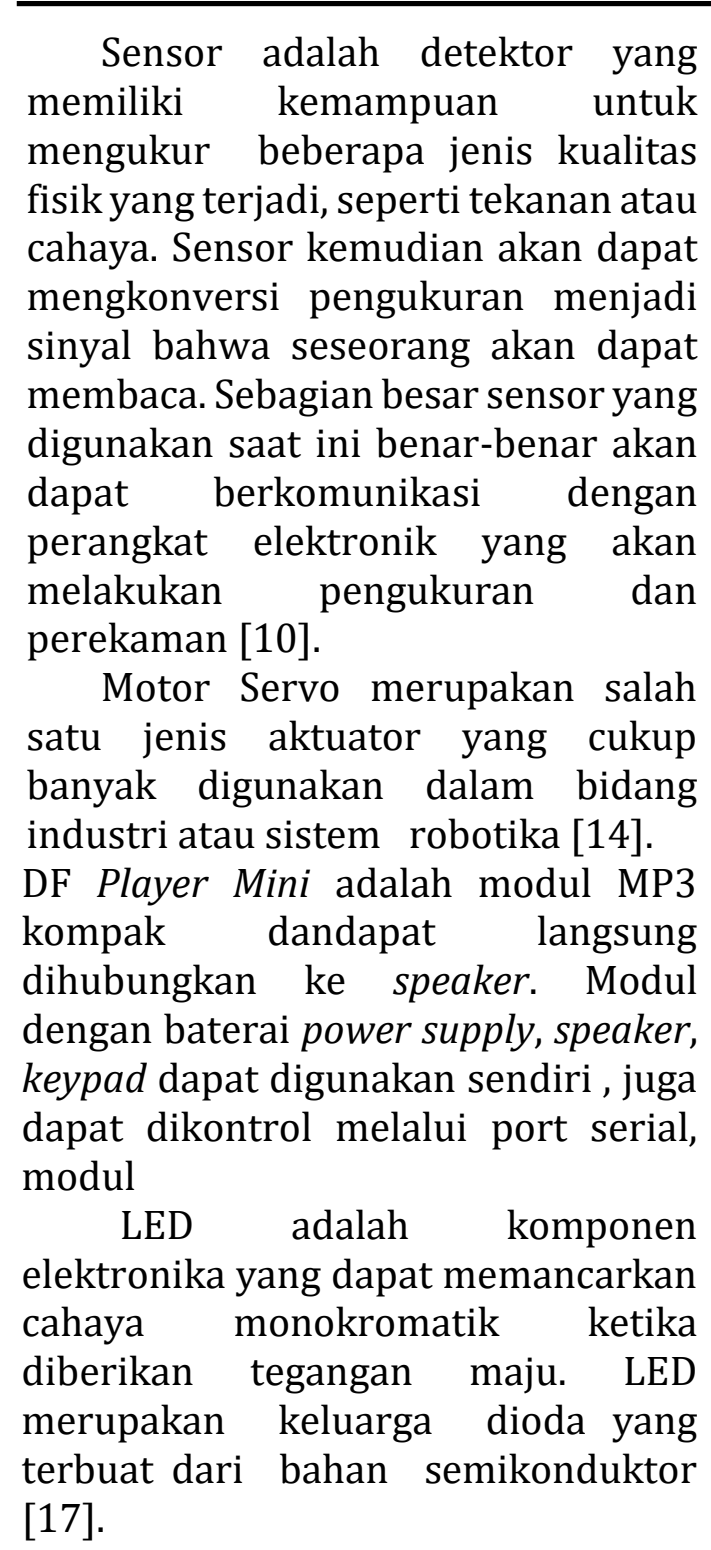

\section{HASIL DAN PEMBAHASAN}

Berdasarkan data hasil pengujian didapatkan bahwa sensor PIR bekerja ketika objek manusia pada jarak lebih dari $0 \mathrm{~cm}$ hingga kurang dari $120 \mathrm{~cm}$. Untuk suara yang dikeluarkan mengikuti respon dari sensor PIR. Jika sensor PIR mendeteksi maka suara akan aktif jika tidak merespon maka suara tidak akan aktif.

Rangkaian perintah suara. Pengujian pada rangkaian ini bertujuan mengetahui sensitifitas sensor voice recognition v3 dalam mendeteksi perintah suara. Sensor ini akan diletakkan pada bagian satu booth dengan arduino sedangkan microphone diletakan di depan untuk menerima perintah suara anak-anak. Objek yang akan dideteksi dalam pengujian yaitu suara laki-laki dan perempuan dengan perintah suara

(1). Hasil Pengujian. Pengujian yang dilakukan meliputi rangkaian perangkat keras (hardware) dan perangkat lunak (software) dengan tujuan untuk mengetahui apakah masing-masing bagian serta keseluruhan sistem dapat bekerja sesuai dengan yang diharapkan. (1) Rangkaian Pendeteksi Keberadaan Anak-anak. Pengujian pada bagian rangkaian ini bertujuan mengetahui sensitifitas sensor dalam mendeteksi objek baik pada jarak terdekat dan terjauh terhadap objek yaitu anakanak yang jalan melewati di depan alat TCT (Trash Can Talk) kemudian DF mp3 mini player akan memainkan suara ajakan anak untuk membuang sampah pada tempatnya yang dikeluarkan melalui speaker untuk menarik perhatian anak-anak. Sensor ini akan diletakkan pada bagian depan yang menghadap keluar dimana dilakukan lima kali percobaan dari tiap objek pada jarak $0 \mathrm{~cm}$ hingga $120 \mathrm{~cm}$. Untuk pengukuran jarak setiap percobaan menggunakan ukuran lantai yang digunakan di sekolah yaitu $30 \mathrm{~cm}$ x 30 $\mathrm{cm}$. Module DF mini mp3 player akan diisi micro SD yang berukuran 1 GB dengan sistem format FAT sedangkan untuk format suara yaitu format *mp3. Dihubungkan dengan ditambahkan resistor $2 \mathrm{k}$ ohm untuk mengurang noise pada suara. 
Ida Afriliana ${ }^{1}$, Andi Setiawan ${ }^{2}$, Andre Juan Taftazani ${ }^{3}$, Heki Rahayu Navita ${ }^{4}$, Imam Bukhari ${ }^{5}$

\begin{tabular}{llll}
\hline \multicolumn{3}{c}{ TABEL 1. PENGUJIAN RANGKAIAN } \\
\multicolumn{3}{c}{ PENDETEKSI ANAK-ANAK } \\
\hline $\begin{array}{l}\text { Jara } \\
\mathbf{( c m}\end{array}$ & $\begin{array}{l}\text { Keadaan } \\
\text { Diam }\end{array}$ & $\begin{array}{l}\text { Keadaan } \\
\text { Bergerak }\end{array}$ & $\begin{array}{l}\text { Suar } \\
\text { a }\end{array}$ \\
\hline 0 & Tidak & Terdeteksi & Aktif \\
& terdeteksi & & \\
30 & Terdeteksi & Terdeteksi & Aktif \\
60 & Terdeteksi & Terdeteksi & Aktif \\
90 & Terdeteksi & Terdeteksi & Aktif \\
120 & Tidak & Tidak & Tidk \\
& terdeteksi & terdeteksi & Aktif \\
\hline
\end{tabular}

(1) yang tekanan intonasi dan jenis nada suara yang berbedabeda untuk menggerakkan motor servo sehingga TCT (Trash Can Talk) akan terbuka secara otomatis dengan jarak antara anak-anak dan microphone dihitung dari jarak $5 \mathrm{~cm}$ hingga kurang dari $30 \mathrm{~cm}$ dan setelah itu module DF mini mp3 player akan memainkan suara untuk memotivasi anak-anak yang telah tertib membuang sampah pada TCT (Trash Can Talk)

Berdasarkan tabel pengujian ini dapat disimpulkan bahwa suara lakilaki maupun perempuan dengan perintah yang sama sekalipun jika berbeda dengan perintah yang sudah terekam di voice recognition tidak bisa membuka TCT(Trash Can Talk).

\begin{tabular}{|c|c|c|c|c|}
\hline No & $\begin{array}{l}\text { Suara } \\
\text { masukan } \\
\text { dengan } \\
\text { rekaman }\end{array}$ & Intonasi & $\begin{array}{l}\text { Motor } \\
\text { Servo }\end{array}$ & Speaker \\
\hline 1. & Sama & Sama & Aktif & Aktif \\
\hline 2. & $\begin{array}{l}\text { Tidak } \\
\text { Sama }\end{array}$ & Sama & $\begin{array}{l}\text { Tida } \\
\mathrm{k} \\
\text { Aktif }\end{array}$ & $\begin{array}{l}\text { Tidak } \\
\text { Aktif }\end{array}$ \\
\hline 3. & Sama & $\begin{array}{l}\text { Tidak } \\
\text { Sama }\end{array}$ & $\begin{array}{l}\text { Tida } \\
\mathrm{k} \\
\text { Aktif }\end{array}$ & $\begin{array}{l}\text { Tidak } \\
\text { Aktif }\end{array}$ \\
\hline 4. & $\begin{array}{l}\text { Tidak } \\
\text { Sama }\end{array}$ & $\begin{array}{l}\text { Tidak } \\
\text { Sama }\end{array}$ & $\begin{array}{l}\text { Tida } \\
\mathrm{k} \\
\text { Aktif }\end{array}$ & $\begin{array}{l}\text { Tidak } \\
\text { Aktif }\end{array}$ \\
\hline
\end{tabular}

TABEL 2. PENGUJIAN SUARA
Berdasarkan data hasil pengujian didapatkan bahwa sensor voice recognition $\mathrm{v} 3$ bekerja dengan baik digunakan untuk perintah suara haruslah sama dengan suara dengan tekanan intonasi dan nada pada saat dilakukan perekaman suara pada sensor voice recognition v3. Perintah suara yang dimasukkan pun harus sama persis dengan suara yang telah terekam sebelumnya di sensor voice recognition dengan intonasi yang sama. Keakuratan tergantung pada tekanan dan nada yang dimasukkan melalui microphone. Untuk bahasa tidak mempengaruhi dalam hal ini. Bahasa Indonesia maupun Bahasa Inggris dapat ditangkap dengan baik oleh sensor voice recognition TABEL 3. PENGUJIAN JENIS SUARA

\begin{tabular}{|c|c|c|c|c|}
\hline No. & $\begin{array}{l}\text { Masuka } \\
\text { n Suara } \\
\text { Laki- } \\
\text { laki dan } \\
\text { Peremp } \\
\text { uan } \\
\text { dengan } \\
\text { rekama } \\
\text { n suara }\end{array}$ & $\begin{array}{l}\text { Intonas } \\
\text { i }\end{array}$ & $\begin{array}{l}\text { Motor } \\
\text { Servo }\end{array}$ & Speaker \\
\hline 1. & Sama & Sama & Aktif & Aktif \\
\hline 2. & $\begin{array}{l}\text { Tidak } \\
\text { sama }\end{array}$ & Sama & $\begin{array}{l}\text { Tidak } \\
\text { Aktif }\end{array}$ & $\begin{array}{l}\text { Tidak } \\
\text { Aktif }\end{array}$ \\
\hline 3. & Sama & $\begin{array}{l}\text { Tidak } \\
\text { Sama }\end{array}$ & $\begin{array}{l}\text { Tidak } \\
\text { Aktif }\end{array}$ & $\begin{array}{l}\text { Tidak } \\
\text { Aktif }\end{array}$ \\
\hline 4. & $\begin{array}{l}\text { Tidak } \\
\text { Sama }\end{array}$ & $\begin{array}{l}\text { Tidak } \\
\text { Sama }\end{array}$ & $\begin{array}{l}\text { Tidak } \\
\text { Aktif }\end{array}$ & $\begin{array}{l}\text { Tidak } \\
\text { Aktif }\end{array}$ \\
\hline
\end{tabular}

Berdasarkan tabel pengujian ini dapat disimpulkan bahwa suara lakilaki maupun perempuan dengan perintah yang sama sekalipun jika berbeda dengan perintah yang sudah terekam di voice recognition tidak bisa membuka TCT(Trash Can Talk).

TABEL 4. PENGUJIAN SUARA DENGAN JARAK 
TCT (Trash Can Talk) Berbasis Arduino Dengan Sistem Solar Cell Untuk Sarana Pembelajaran Perilaku Tertib Buang Sampah pada Anak

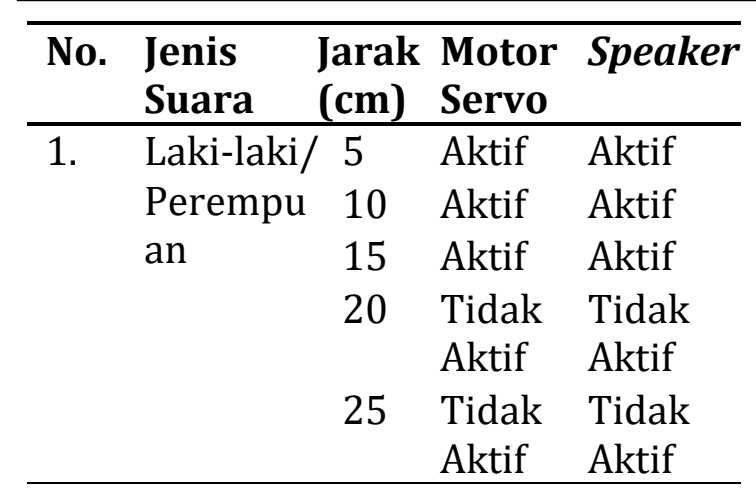

Berdasarkan tabel pengujian diatas dapat disimpulkan untuk jarak antara suara dengan microphone cukup berpengaruh. Maksimal dari pengujian ini yaitu dengan jarak kurang

Solar panel dengan ukuran 3 WP (Wattt Peak) dengan open circuit tegangan 10,8 volt dengan tegangan stabilnya 12 volt. Untuk menyimpan daya dari solar panel dipilih aki dengan ukuran tegangan 12 volt dengan arus 3

Berdasarkan tabel pengujian diatas dapat disimpulkan, bahwa semua alat dalam rangkaian notifikasi dapat bekerja dengan baik dengan maksimal jarak yang dapat memberikan notifikasi bahwa TCT (Trash Can Talk) telah penuh adalah kurang dari $180 \mathrm{~mm}$, yang telah di atur pada coding.

(4) Rangkaian Sistem Solar Cell. Pengujian pada rangkaian ini bertujuan untuk menguji sistem kerja solar cell untuk memberikan daya kepada TCT (Trash Can Talk) agar dapat bekerja dengan baik. Dalam hal ini, perhitungan ukuran solar cell harus sangat diperhatikan dengan daya yang dibutuhkan dengan pemilihan solar panel dengan baterai dan solar charger controller harus sesuai.

Perilaku Tanggapan Total

\begin{tabular}{|c|c|c|c|c|c|c|}
\hline & \multicolumn{2}{|c|}{$\underset{\mathrm{f}}{\text { Negati }}$} & \multicolumn{2}{|c|}{ Positif } & & \\
\hline & $\mathrm{n}$ & $\%$ & $\mathrm{n}$ & $\%$ & $\mathrm{~N}$ & $\%$ \\
\hline Buruk & 5 & $\begin{array}{c}29 \\
4\end{array}$ & $\begin{array}{l}1 \\
2\end{array}$ & $\begin{array}{c}70, \\
6\end{array}$ & $\begin{array}{l}1 \\
7\end{array}$ & $\begin{array}{c}10 \\
0\end{array}$ \\
\hline Baik & 1 & $\begin{array}{c}14, \\
3\end{array}$ & 6 & $\begin{array}{c}85 \\
7\end{array}$ & 7 & $\begin{array}{c}10 \\
0\end{array}$ \\
\hline Jumlah & 6 & 25 & $\begin{array}{l}1 \\
8\end{array}$ & 75 & $\begin{array}{l}2 \\
4 \\
\end{array}$ & $\begin{array}{c}10 \\
0\end{array}$ \\
\hline
\end{tabular}

alat sensor DF mini mp3 player.

(3) Hasil Survey. Dalam penerapannya TCT (Trash Can Talk) ini diperkenalkan kepada siswa-siswi di SD Negeri Gumalar 01 pada hari Senin, 15 Juli 2019 melalui kuisioner yang

A. Keluaran solar charge controller yang digunakan yaitu dengan 12 volt dan arus maksimum $10 \mathrm{~A}$. Untuk suhu dalam penggunaan sistem solar cell dengan rata-rata suhu 44 0C untuk pengisian baterai. Untuk arduino dihubungkan pada output dari stepdown yang dihubungkan di output solar charger controller yaitu 5 volt.

Saat pengujian, pengisian aki hanya sampai pada 10,8 volt yang dapat terisi oleh solar panel dikarenakan open circuit solar panel maksimum hanya sampai pada 10,8 volt. Artinya, jika akan mengisi sampai penuh 12 volt harus dengan ukuran solar panel yang lebih besar dengan open circuit nya mencapai 12 volt. Untuk pengisian tercepat $5 \mathrm{~A}$ pada aki 12 volt ini dibutuhkan waktu 30 menit namun karena dari short circuit current solar panel ukuran 3 Wp hanya 0,367 A maka butuh waktu 3 jam lebih pengisian dengan tegangan maksimumnya 10,8 volt. Untuk penggunaan pasif dalam 5 hari hanya kehilangan daya 0,5 volt artinya satu hari kehilangan 0,1 volt. Sehingga disimpulkan bahwa ukuran solar panel harus lebih besar daripada 
ukuran baterai atau aki. Dan ukuran baterai atau aki harus lebih dari minimum tegangan dari solar charger controller agar dapat mengeluarkan output. Pengisian baterai dari solar panel dengan aturan, jika baterai berada di tegangan 9 volt maka solar panel otomatis akan mengisi tegangan baterai dan jika aki sudah berada di tegangan 10,2 volt maka solar panel akan berhenti mengisi baterai.

(2) Pengujian Software. (1) Coding Pendeteksi Keberadaan Anakanak.Penulisan coding dengan aplikasi dapat diuji validitasnya tanggapan para siswa-siswi setelah mengenal TCT (Trash Can Talk) dengan sample kelas 6 yang berjumlah 24 anak.

Hasil analisis hubungan antara perilaku membuang sampah dengan tanggapan adanya TCT (Trash Can Talk) diperoleh bahwa responden yang berperilaku buruk membuang sampah memiliki tanggapan negatif adanya TCT (Trash Can Talk) yaitu 29,4\% lebih besar dibandingkan responden yang berperilaku baik membuang sampah memiliki tanggapan negatif adanya TCT (Trash Can Talk) yaitu 14,3\%.

\section{KESIMPULAN}

(1) Kesimpulan. Berdasarkan pengujian, hasil penelitian dan implementasi TCT (Trash Can Talk) Berbasis Arduino dengan Sistem Solar Cell untuk Sarana Pembelajaran Perilaku Tertib Buang Sampah dapat diambil kesimpulan dibawah ini : (1) TCT (Trash Can Talk) dapat berjalan dengan baik sesuai rancangan sistem. Dapat menerima perintah suara dan mengeluarkan suara untuk menarik anak-anak agar tertib membuang sampah. (2) Untuk penerapan sistem solar cell mudah dalam pemasangan namun harus memperhatikan dari segi ukuran kebutuhan komponen dengan output daya, tegangan, dan arus dari solar panel dan solar charger controller. Yang harus diperhatikan dalam pemilihan solar panel yaitu ukuran open circuit dari solar panel dan maksimum tegangan dari solar charger controller nya. (3) Dalam survei Arduino IDE yang harus sudah dilengkapi dengan library sensor PIR dan library DF mini master $\mathrm{mp} 3$ player agar dapat mengakses alat sensor PIR dan DF mini mp3 player. (2) Coding Perintah Suara. Penulisan coding dengan aplikasi Arduino IDE yang harus sudah dilengkapi dengan library voice recognition V3, DF mini master mp3 player agar dapat mengakses alat sensor voice recognition V3 dan DF mini mp3 player.(3)Coding Notifikasi Penuh. Penulisan coding dengan aplikasi Arduino IDE yang harus sudah dilengkapi dengan library DF mini master mp3 player agar dapat mengakses

hari Senin, 15 Juli 2019. Sebagian besar 87,5\% tanggapan responden positif terhadap adanya TCT (Trash Can Talk) dan sebesar 12,5\% memiliki tanggapan responden negatif terhadap adanya TCT (Trash Can Talk).

Saran. Berdasarkan hasil penelitian, saran untuk pengembangan sistem lebih lanjut antara lain : (1) Kecocokan intonasi dan perintah suara harus diperhatikan dalam membuka (Trash Can Talk) jika tidak cocok dengan suara yang telah terekam sebelumnya oleh sensor voice recognition v3 maka TCT (Trash Can Talk) tidak akan membuka. Sehingga perlu adanya 
TCT (Trash Can Talk) Berbasis Arduino Dengan Sistem Solar Cell Untuk Sarana Pembelajaran Perilaku Tertib Buang Sampah pada Anak

proses perekaman terlebih dahulu sebelum penerapan dalam membuka TCT (Trash Can Talk). (2) Penggunaan dalam mendeteksi perintah suara sebaiknya menggunakan sensor easy vr yang dapat menampung lebih banyak dan memiliki tingkat keakuratan yang lebih bagus daripada voice recognition v3. (3) Notifikasi penuh bisa ditambahkan implementasi TCT (Trash Can Talk) di kelas 6 SD Negeri Gumalar 01 pada 10 wp untuk baterai atau aki ukuran 12 volt. dengan module sms kepada petugas kebersihan selain dari peringatan suara. (4) Ukuran solar panel sebaiknya lebih besar dari ukuran yang digunakan dalam penelitian ini. Direkomendasikan ukuran solar panel 


\section{REFERENCE}

[1] Gusti, A., I., dkk. 2015. "Hubungan pengetahuan, sikap dan intensi perilaku pengelolaan sampah berkelanjutan pada siswa sekolah dasar di Kota Padang”. Jurnal Dinamika Lingkungan Indonesia, 2 (2):hal.100-107.

[2] Abdurrahman,B.2014. Media Pembelajaran Huruf Latin Dan Hijaiyah Brailledengan Output Suara Untuk Siswa Tunanetra Di SLB A Yaketunis Yogyakarta. Jurusan Pendidikan Teknik Elektronika Fakultas Teknik Universitas Negeri Yogyakarta : Skripsi.Tidak diterbitkan.

[3] Pramanta,F.,D., 2016. Smile Trash (Smart Learning Trash) Tempat Sampah Pembentuk Karakter Anak Bangsa. Universitas Negeri Malang. Karya Tulis Ilmiah.

[4] Sukarjadi, dkk. 2017. Perancangan dan Pembuatan Smart Trash Bin Berbasis Arduino Uno. Teknik Elektro Politeknik Sakti : Tugas Akhir. Tidak diterbitkan.

[5] Ubaidillah, D. 2015. Perancangan Sistem Smart Trash Can Menggunakan Arduino Dengan Sensor Ultrasonic HC-SR04. Teknik Informatika STMIK AMIKOM Yogyakarta : Skripsi.

[6] Saptaji, Handayani W. 2015. "Mudah Belajar Mikrokontroller dengan Arduino". Bandung : Widya Media.

[7] Diana, A. \& Setiawati, L. 2011. "Sistem Informasi Akuntansi, Perancangan, Prosedur dan Penerapan". Edisi Pertama.Yogyakarta: Andi.

[8] Dr. Junaidi, S.Si., M.Sc dan Prabowo, Dwi Yuliyan. 2018. "Project Sistem Kendali Elektronik Berbasis Arduino". Bandar Lampung : Anugrah Utama Raharja.

[9] Astari, S., dkk. 2013. Kran Air Wudhu Otomatis Berbasis Arduino Atmega 328. Fakultas Teknik Universitas Maritim Raja Ali Haji : Skripsi.

[10] Humairah. 2014 ."Dakwah itu JOM!". Jakarta : Dwen Prints.

[11] Rafiuddin S, PhD. 2013. "Dasar Dasar Teknik Sensor Untuk beberapa kasus sederhana". Makassar : Fakultas Teknik Universitas Hasanuddin.

[12] Supriyono I., A., dkk. 2015. Pengukur Tinggi Badan Menggunakan Sensor Ultrasonik Berbasis Mikrokontroler Atmega328 Dengan Output Suara. S1 Teknik Informatika STMIK Raharja : Tugas Akhir. Tidak diterbitkan.

[19] Sagita, Mela. 2015. Aplikasi Led RGB Pada Lengan Robot Penyortir Kotak Berdasarkan Warna Berbasis Arduino Uno. Jurusan Teknik Elektro Politeknik Negeri Sriwijaya : Tugas Akhir. Tidak diterbitkan

[13] Silvina, N. 2017. Aplikasi Sensor Voice Recognition Dalam Sistem Keamanan Brankas. Jurusan Teknik Elektro Politeknik Negeri Sriwijaya : Tugas Akhir. Tidak diterbitkan.

[14] Taher, Razali. 2017. Alat Pembuka Tutup Kotak Sampah Otomatis Dan Pendeteksi Volume Sampah. Jurusan Teknik KomputerPolitek7nik Negeri Sriwijaya : Tugas Akhir. Tidak diterbitkan.

[15] Murethania, S. 2011. Rancang Bangun Alat Pencatat Pemakaian Daya Pelanggan Listrik PLN Secara Portable. Jurusan Teknik Komputer Politeknik Negeri Sriwijaya : Tugas Akhir. Tidak diterbitkan.

[16] Malyan, A. B. J \& Surfa Yondri. 2012 ."Pengendali Beban Listrik Menggunakan Hand Phone Melalui Misscall". Elektron Jurnal Ilmiah: Vol.4, No 2. 